\title{
The Human Capital in Seloka Pak Kaduk
}

\author{
Nor Hasimah Ismail \\ Pusat Pengajian Bahasa, Tamadun dan Falsafah \\ Universiti Utara Malaysia \\ Sintok, Kedah, Malaysia \\ nhsimah@uum.edu.my \\ Melor Fauzita Binti Md. Yusoff \\ Pusat Pengajian Bahasa, Tamadun dan Falsafah \\ Universiti Utara Malaysia \\ Sintok, Malaysia \\ fauzita@uum.edu.my
}

\author{
Nazilah Mohamad \\ Fakulti Bahasa dan Komunikasi \\ Universiti Sultan Zainal Abidin \\ Terengganu, Malaysia \\ nazilahmohamad@unisza.edu.my \\ Julizayati Binti Shukor \\ SMK Tan Sri Abdul Kadir \\ Johor, Malaysia \\ julizayatishukor@yahoo.com
}

\begin{abstract}
Seloka is one of the traditional Malay poems which is a complete union of content or idea as a kind of poem that contains teachings such as sarcasm and jokes. In terms of the form of a seloka contains two, four or more lines. Seloka content usually consists of sharp satirical messages. Human capital can be interpreted to three important aspects, that is an excellent aspect of character, a strong and integrity principle and philosophy. Integrity is a visionary, structured design and polite treatment. The development of human capital should be given due attention, because quality human capital is an important element in the achievement of national missions should be done holisticall. There are several values in Seloka Pak Kaduk that can help build the soul and the individual and external aspects of an individual. The acquired human capital is able to produce people who think rationally, creative and critical.
\end{abstract}

Keywords—seloka; satire; joke; rational; creative

\section{INTRODUCTION}

Traditional Malay poetry belongs to a group of poems that emerged and produced in the traditional era. Seloka is one of the examples of traditional Malay poetry. Seloka is also a complete union of content or idea. [1] explains seloka derived from the Sanskrit language, which is "sloka" which means a defective catchment.

Seloka is a kind of poem that usually consists of two, four or more lines. Seloka is arranged in a catchy manner but each function is not fixed its number. As such, seloka is not the same as rhythm finally and rhythmically free. Seloka content usually consists of jokes and sharp satirical messages. In addition, seloka is also used as a guide in comparisons and simulations such as imagery, metaphors, personification and simile that are full and rich in natural elements and images.

There are seven types of seloka contained in the seloka group belonging to the Malay community. Among them are seloka satire, mockery seloka, seloka chase, advice, teaching lesson, fantasy seloka and jokes. The obvious function of a seloka is to give criticism and satire to an issue that occurs in a society. All the criticisms and satirites given are peddled and cultivated. This is to avoid feeling offended by individuals aimed at such satirical and criticisms. [1] states that the satire in seloka can be jokes or serious and may contain other elements such as fun, sensual, fantasy and dream. The contents of the seloka are also often related to the folk stories that are commonly known as Pak Kaduk, Lebai Malang, Nujum Pak Belalang and others [2].

In addition, the creation of this seloka has been the evidence of the value inherent in the Malay community, the value of politeness. This is because the creation of a seloka as a medium to convey dissatisfaction with something that illustrates the attitude of the Malay community that cares for the harmony and incompetence of criticism and opinion. In total, the sequel refers to a joke story that has been really known in society such as Pak Kaduk's story, Pak Pandir's story, the story of Lebai Malang and the story of Emak Si Randang. The aim is to unleash the members of the warring society like those figures. Seloka usually contains the language that his story is swirling and moving, his vigorous sarcasm is always sharp and can be like mocking and clinging and containing a feeling of humbling and vulnerable $(2007 \mathrm{~b}$ : 218).

\section{A. The Definition of Human Capital}

Human capital can be interpreted to three important aspects, namely the excellent aspects of the personality, the philosophy and the principles of strong and integrity. Integrity is a visionary, structured design and polite treatment. This human capital development should be given special attention especially to current students. This is because, this quality human capital of the nation is an important element in achieving the national mission. This human capital construction should be done holistically.

The construction of the human capital to be produced must include a strong, competent, high profile and knowledgeable aspect. Through education whether from home, school or government or non-governmental organizations it is capable of injecting value-added, intellectual and cultural value in the human capital aspect that has been produced. 


\section{VALUE ANALYSIS IN SELOKA PAK KADUK}

Based on the analysis, there are seven values found in Seloka Pak Kaduk. Among the seven values is the value of rationality, wisdom, obedience, frugality, love, honesty and justice. Refer to Appendix 2 for Seloka Pak Kaduk's temples.

\section{A. Value of Rationality}

The rationale can be defined as a reasonable reasoning that underlies any action, deed or handle $(2007 \mathrm{a}$ : 1292). In Seloka Pak Kaduk, this value can be questioned and seen through Pak Kaduk's treatment. Pal Kaduk should reasonably think and act rationally. However, what happens is the opposite because he does not think long and can be said to think insupportable. This is because Pak Kaduk is willing to risk his sole property asset, the land as a collateral for the fighting of the king's scourge. Pak Kaduk seems to be too optimistic and convinced that he will win and be very good at making a decision in a very short period of time.

This cynicism categorically states that all the problems that come are usually due to self-negligence. This app is a form of advice when doing something to use mind and caution. If this is not the case (Aripin Said, 1994: 66). This clearly shows Pak Kaduk's attitude in a hurry making his own disadvantage. As a result of not thinking deeply, he lost his ground and caused him to settle down in another's home.

\section{B. Value of Wisdom}

Wise can be defined as a matter of intellect (2007a: 183). In Seloka Pak Kaduk it is clear that Pak Kaduk is a person who does not use common sense when doing something. For example, the paddle paddling for wanting to go home. This incident happened when Pak Kaduk wanted to sail upstream, he followed the low tide, when he wanted to get down to Pak Kaduk downstairs. This means that Pak Kaduk has taken the water stream. This action led Pak Kaduk to take a long time to get home. This clearly proves that Pak Kaduk is a straight and somewhat stupid one.

Besides that, Pak Kaduk also happily proclaimed his chickens, Si Kunani as the winner in a chickens contest with the king. Pak Kaduk was too happy to cheer on tearing his shirt made out of paper and was digged by his wife, Mak Siti. This action shows Pak Kaduk's idiot who did not realize that he had changed his chickens with the king.

\section{Value of Obedience}

Obedience can be defined as a heartfelt heart toward religion and righteousness (2007a: 1561). This can be explained by Pak Kaduk's character who did not practice Islam properly. The likes of gambling have been mixed in Pak Kaduk. Although it is said this habit is simply fun to entertain after tired work, but this habit is still classified as gambling. This habit is strictly forbidden in religion because it is very harmful to the gambler. The proof, Pak Kaduk has lost his home and land due to his heartfelt desire by betting for a cockfighting match. As a result of the struggle that made Pak Kaduk's life often misunderstood and distressed.
Furthermore, due to the lack of religious knowledge and not obeying orders and religious instruction, Pak Kaduk easily controlled the emotions and passions. As a result, he has killed his wife for not being able to withstand his wife's folly and madness.

\section{Value of Thrifty}

The nature of the frugality is necessary to all individuals either from the superior or the subordinates. In Seloka Pak Kaduk, Pak Kaduk is a waste of time and is not thrifty. This is evident when Pak Kaduk is able to pour and throw rice during his journey. The rice should be a dish when starving.

In addition, Pak Kaduk also does not want to work hard and greedy. He briefly agreed to change his chickens with the king and was consumed by the empty "talk" of the king if his new chickens won. Pak Kaduk is convinced that victory is on his side and is eager to receive "rewards" from the king.

\section{E. Value of Love}

Love is an important element in the formation of a happy family. In Seloka Pak Kaduk, this value can be seen through Pak Kaduk's wife. Pak Kaduk's wife, Mak Siti, often wails and scolds Pak Kaduk for his ignorance and his perilous actions. This act is a sign of a wife's concern for her husband in order to make her husband change and act on a rational mind.

In addition, Pak Kaduk's affection for his wife was also visible because Pak Kaduk remained patient with his wife's blunt until the Pak Kaduk incident was tired because of the lack of knowledge in the cruise until late into the house and in hunger. Pak Kaduk acted to hit his wife and the affection had vanished in Pak Kaduk.

\section{F. Value of Honesty}

Honesty is very important in a matter of business which involves an agreement between the two parties. In Seloka Pak Kaduk, the actions of the king who took advantage of the Pak Kaduk's idiot had caused Pak Kaduk to lose. The deal involving this bet can be regarded as gambling. The gambling is certainly running away from the concept of honesty and sincerity. So, it is not surprising that Pak Kaduk lost his land, wife and home after losing the cockfighting battle.

Pak Kaduk was also betrayed by the king through the exchange of the chicken. The symbolism of this incident proved that Pak Kaduk was very easy to believe in the words of a newly discovered individual without regard to the sincerity and honesty of the promise made by the individual. As a result of his lunacy, Pak Kaduk proudly stated that his chickens were victorious in betting for forgetting the decree that had been made before the fight began.

\section{G. Value of Justice}

The concept of justice expressed here is justice to ordinary people like Pak Kaduk. The existence of a leader like 
the king in Seloka Pak Kaduk has caused the common people, especially subordinates, to live in distress and uneducated to become victims of greed.

The proof is that the king is willing to take Pak Kaduk's land even though he knows the lives of ordinary people who are unlucky. Additionally, Pak Kaduk's actions pulled out shirts and trousers made from paper and were glued by his wife as a symbol of Pak Kaduk's "excitement" on the basis of his chickens victory, Si Kunani. However, it may be that joy is a mere act of pursuit of the heart and as a symbol of obedience to the king who at that time was extremely obliged and must obey and acknowledge all his commands and instructions. As a result, the people who became victims of the loss of justice in government.

\section{ANALYSIS OF VALUE IN SELOKA PAK KADUK WITH THE POSITIVE ATTRIBUTE AMONG STUDENTS}

Based on value analysis in Seloka Pak Kaduk, there are seven links between the values in Seloka Pak Kaduk and the construction of student human capital. Among the links is to produce students who are objective, ethical, knowledgeable, moderate, caring, disciplined and skilled. All aspects of developing the student's human capital include spiritual (intellectual and ethical), humanitarian (loving and moderate), self-esteem (goals and skills) and physical (disciplined).

\section{A. Value of Rationality Produce Students with Vision (Be Objective)}

When rational values are based on the thinking and every action of a student, then they will have the initiative to reflect on themselves. This self-reflection session will encourage students to think and strive to balance the demands or needs that they face. Through this rational value, the students will strive to think and make the best choice for themselves in turn building goals.

Students should not emulate the character of Pak Kaduk, who does not think long. As a result of not thinking long, Pak Kaduk lost his wife, house and land. Students with high levels of human capital will work towards achieving the goals set. For example, a student desires to get excellent results in the lesson. The students must work to ensure their goals are met. Additionally, education is the ultimate pulse and the dominant weapon in producing a student who aims to have high human capital.

The education that is meant is education from parents. Parents should work together by practicing moral values in the lives of children since they are young. Setting a goal from small to them to be a kind person and think before acting greatly influences the child's enlargement process. Once grown up, they will be able to practice the practices that have become their daily routine with ease. Those who hold children at home and hold student status at school will try to avoid things that can prevent their life's goals. This type of student is able to make an analysis when doing any act or decision. They will avoid things that are unhealthy, such as social problems or will never pawn or risk their self-esteem for their own loss and future.

\section{B. Value of Wisdom led to Ethical Students}

Ethics is a rule that exists in human thought and is manifested through action. Through the ethics inherent in the individual, the individual is able to determine the deeds done either true or false. The relevance of this ethical character with the wisdom value can be explained by the character shown in the student. These ethical students will be wise in arranging their daily routine to be structured. For example, in the selection of friends. Students who are ethical are wise in choosing and associating with friends who will benefit them. The value of wisdom inherent in them helps them to develop themselves in terms of communication and communication.

Wise students will have manners and ethics when communicating with teachers, friends, parents and people around them. Wise students will also be conversant with current issues and able to argue and discuss high-profile topics such as global issues. Students of this type will also be far from the nature of Pak Kaduk, which is faint and confusing when in trouble. They will become active and able to think analytically and critically.

\section{Value of Obedience Produce Knowledgeable Students}

The value of obedience meant is obedience to the Creator, namely God. In this context, students who are obedient to God will know the importance and duty of learning. The science that is claimed is not only religious knowledge, but even its scope is so vast that it entitles these students out of the individual cocoon of their ignorant religion. In fact, these students will not appreciate the value inherent in Pak Kaduk, a gambling habit.

Through the value of obedience to God, students are able to build human capital in terms of character formation. Good manners will encourage students to love and crave knowledge. Thus, young people who love science and unity will be born. Every act and decision made is based on knowledge and values of obedience to God. Human capital in this aspect of personality, that is, the development of the mind by loving this knowledge focuses on the aspects of humanity. This aspect of the humanity is built through the philosophy of life, religious and moral support contained in one's individual. The growth rate of adherence value should be nurtured since childhood and streamlined through the education system. Teachers also play a role by encouraging students to love knowledge in addition to obedience to religious orders and instructions.

\section{Value of Thrifty Cultivate Students to Live in Modest}

Considerable values can be nurtured among students since they are still small. This value can be expressed by the cultivation and encouragement of saving practices. This saving practice is a skill that needs to be in the soul of a student. This is because through this practice, students are able to adapt to any situation or situation experienced or in other words, living in moderation. 
Pak Kaduk's character in Seloka Pak Kaduk as his gambling bad habits can be avoided if students are exposed to the practice of saving since childhood. They can think and determine that gambling habits are a waste and should be avoided.

Applying these value-for-money values should be done in collaboration with government agencies and nongovernmental organizations as well. Advertising on television shows about the good of saving money and certain campaigns through the ministry can be done. An initial disclosure between the two government agencies and non-governmental organizations can help in developing the human capital aspect to be simpler in all respects. Being modest in everything can make the life of an individual more structured.

\section{E. Value of Love Led to Cultivate Loving Students}

The value of love that exists in the student is able to make the students love the people around them. In this context, love is very important in a family and should be nurtured ever since. Parents' attention is indispensable for loving children. Lack of attention and affection from the family causes the emergence of social symptom cases. This is because students especially teenagers now face challenges and competition from various sources. More and more of these times are based on the maximum knowledge of the latest technology.

Sufficient love and rising values in the soul of students will cause students not to make ipad, iphone or laptop as their closest friends. They will not be upset with the latest gadgets. In fact, they will have a close relationship with parents and families at home and take care of manners, morals and relationships while communicating and associating with teachers and friends at school. The value of love that exists in oneself causes students to have a morals and a heart full of love and mutual respect for each other.

In Seloka Pak Kaduk, due to being controlled by mere emotion, Pak Kaduk was willing to beat his wife, Mak Siti with a stick to death. Due to anger, Pak Kaduk's affection for his wife was lost to cause death. Based on these circumstances, students with high human capital also will not do anything based solely on emotion. The value of affection they have in themselves makes them have a sense of appreciation for others. Therefore, this love value can produce a loving child.

\section{F. Value of Honesty Encourage Students to be Discipline}

The honesty value contained in this context is selfhonest. In the case of Pak Kaduk, the attitude of the king who deceived and used Pak Kaduk for his foolishness and ignorance when the chicken mug agreements should not be emulated and should be shunned. If the value of this honesty is applied to the students since they are still young, they are able to grow as a disciplined teenager. The scope of the discipline in question is discipline in speaking of the truth and authenticity in any circumstance. This disciplinary attitude is one of the important things in the construction of student human capital. The existence of discipline in the students will help them become useful people in the future.

Like the words of an Arab poet, Syauqi Bei who states that if he wants to see the future of a country, then look at his younger generation today. Hence, the value of honesty should be a pillar in producing a disciplined young generation. This discipline will help in leading the future government. Moreover, the value of this honesty makes the students always self-reflecting. Through these values, they will always follow their daily routines that cover subject matters, social groups of friends, and teachers and relationships with God and parents.

The attitude of discipline that is formed in itself is able to make the students strive to learn seriously in understanding and practicing every learned knowledge. Failure of students to learn and perform responsibilities as students in the context of education will make them punish themselves. The punishment imposed on yourself is to set a lot more time when reviewing lessons for subjects that are not well-mastered. Hence, the disciplinary attitude that comes from honesty is such as capable of producing a high level of human capital in ensuring success in the field of education to be theirs.

\section{G. Value of Justice Sharpen Students Skill}

The value of this parishionary justice is based on the king's attitude in Seloka Pak Kaduk. A fair king will not take the land of his people through a side-by-side agreement and an abusive way, such as betting on gambling practices. Pak Kaduk's popularity also caused him not to realize that he had been mistreated and consequently the property he had acquired.

Through the value of justice, capable students are born. Such students are capable of being born because students who care about justice to themselves and others have a strong, competitive, knowledgeable, rational in action and practice pure values in life. Skilled students are vocal students in expressing opinions either in the circumstances in which they appear to be inaccurate or unfairly or in any situation that is said to be biased.

This superior self-esteem makes students capable of cultivating leadership and personality through co-curriculum activities. The value of justice taught by the teacher when in the classroom or in the context of the curriculum will be applied in the context of the co-curriculum. This existing skill gives space and opportunity within the student itself to create human capital within themselves. Indeed, these noble values are very important in the individual, especially the students or the younger generation at present. They are the leaders and the heirs of the state, so if the value of justice is applied to the souls of the students, then the leaders who are able to govern themselves, families, communities and nations will be born.

\section{CONCLUSION}

In conclusion, the value contained in Seloka Pak Kaduk has been analyzed and linked to the construction of student human capital. Based on the findings that have been analyzed, it is clear that the value contained in this course should be a 
vehicle for learning by the society, especially students or adolescents. This is because the attitude shown by Pak Kaduk only causes him to be miserable and disadvantaged.

[1] states that Pak Kaduk is also a stupid and greedy character who cannot account for the consequences of his actions; his wife was killed and he was almost dying of starvation. It turned out that the characters were raised from the rational, negative and pest group. In reality there are such characters in a community group or a national family. Then be boundaries to the concerned group do not practice such behavior and do not let such characters continue to exist in a society that wants to develop.

The values found in the cell can be practiced to help build the soul and the internal and external aspects of the students. The acquired human capital is able to produce students who think long, rational and creative and critical. Students also have high resilience and competitiveness in the face of any situation and have skills in solving problems. Ultimately, human capital development among students can be generated through the analysis of values in Seloka Pak Kaduk.

\section{REFERENCES}

[1] Harun Mat Piah et. al (2000). Puisi Melayu Tradisional. Kuala Lumpur : Dewan Bahasa dan Pustaka.

[2] Abdul Halim Ali (2006). Mendekati Puisi Melayu Tradisional. Selangor: Elpos Print Sdn Bhd.

[3] Angela Baron \& Michael Armstrong (2015). Pangurusan Modal Insan. Kuala Lumpur : Institut Terjemahan dan Buku Malaysia.

[4] Aripin Said (1994). Puisi Warisan. Kuala Lumpur : Dewan Bahasa dan Pustaka.

[5] Harun Mat Piah (1989). Puisi Melayu Tradisional. Kuala Lumpur : Dewan Bahasa dan Pustaka.

[6] Pati Anak Aleng (2016). Transformasi Pendidikan dan Pembangunan Modal Insan. Selangor: PTS Publications \& Distributors Sdn Bhd.

[7] Rosli Saludin (2007b). Puisi Melayu Tradisional. Penang: Goal Intelligent Publishing Sdn Bhd.

[8] https://ms.wikipedia.org/wiki/Pembangunan_Modal_Insan:_Teras_ Pendidikan_Negara

[9] http://sangmentari2014.blogspot.my/p/halaman-ilmiah.html 